\title{
Cutaneous Myiasis (Tumbu Fly larvae): A Case Report
}

\author{
CO Onyeama*, PC Njai**
}

\begin{abstract}
Summary
Onyeama CO, Njai PC. Cutaneous Myiasis (Tumbu Fly larvae): A Case Report. Nigerian Jomnal of Paediatrios 2005; 32:26. The invasion of the skin and subcutaneous tissue by the larvae of flies is known as cutaneous myiasis. It can be confused with cutaneous furunculosis and this could result in unnecessary treatment with antibiotics. The case of a six-week old infant who presented with what at first was thought to be furunculosis, but which later turned out to be infestation with the African tumbu fly (Corchlobiaanthropophaga), is described. A total of 47 larvae were extracted from the patient's lesions. The case illustrates the importance of considering myiasis in the differential diagnosis of furunculosis in people living in, and travellers returning from endemic areas.
\end{abstract}

\section{Introduction}

MYIASIS is the invasion of living tissue or organs by the immature stage (larvae) of flies. It is endemic in Africa ${ }^{1}$ and the Americas, and occurs with significantly less frequency in most other parts of the world. The infestation is usually subcutaneous, but has been known to occur in wounds and body cavities. In Africa, the larvae of Tumbu and Lund flies are the species of Dittera usually encountered. Its diagnosis can be confused with that of cutaneous furunculosis. ${ }^{2}$ This communication describes a case of heavy infestation of a six-week old infant by Contylobia anthropophaga .

\section{Case History}

A six-week-old child was admitted to the ward of the MRCLaboratories, Fajara in The Gambia, with a threeday history of multiple eruptions which started from the scalp, but later became more prominent on the dorsal part of the trunk, hands and legs. These lesions were non-suppurating. The child was very restless, cried excessively and could not sleep at night. The mother denied placing the child on the lawn and no other member of the family had similar lesions. However, the patient's clothes were usually dried on the ground and, due to lack of electricity, were never ironed. The child had received antibiotics for the lesions in another health establishment without improvement.

\section{Medical Research Council, Laboratories. Fajara,} The Gambia

\section{Clinical Services \\ "Medical Officer \\ ** Matron}

Email: oonyeama@mrc.gm
Examination revealed a baby with multiple pustules affecting the scalp (occipital), trunk (posterior), dorsum of the arms and the axillae, with a few on the face. (Fig 1)

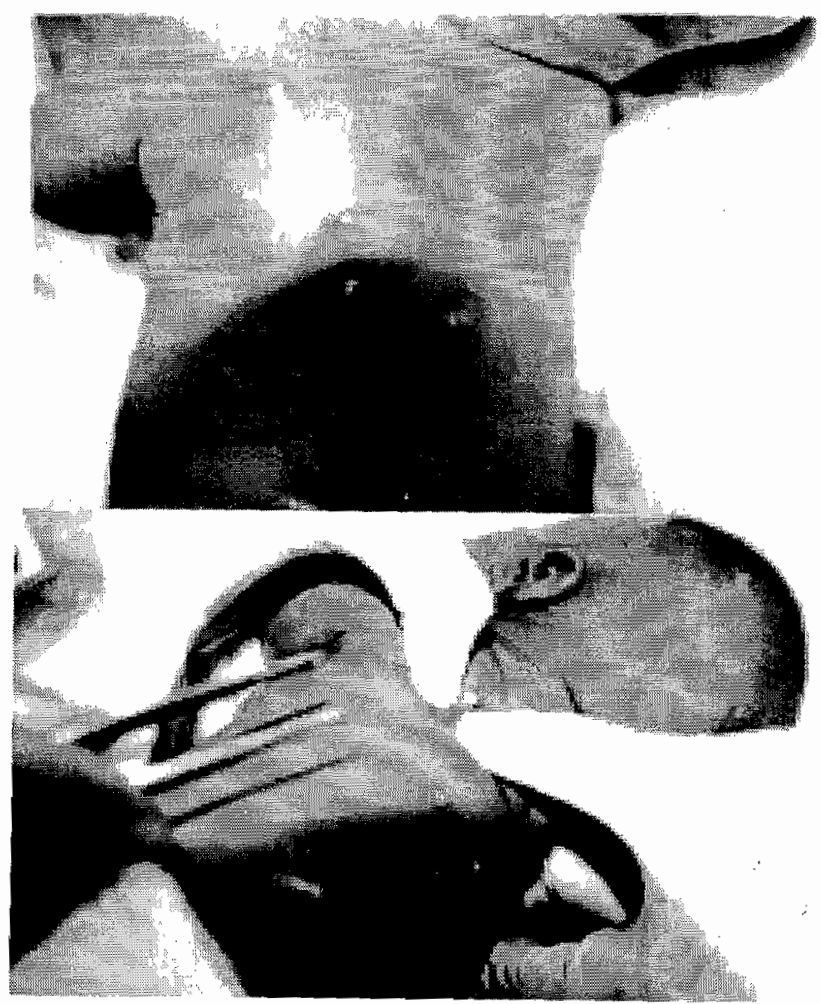

Fig. la 6-week old cbild with multiple "pustular"lesions on the scalp and trumk

They measured $0.2-1.1 \mathrm{~cm}$ in diameter and there were whitish plaques on the puncta of the lesions. An attempt to take a swab for bacterial culture revealed a larva that protruded briefly from one of the lesions. A total of 47 larvae, most of which were alive, were extracted from the infant who slept peacefully immedi- 
ately after the extractions. The mother was subsequently advised against spreading clothes on the lawn for drying. The larvae were identified as that of Tumbu fly [Condylobiaanthropophaga].

\section{Discussion}

Females of Tumbu flies deposit their eggs below the surface of the sandy soil and occasionally on wet and soiled clothes hung outside for drying., The larvae emerge from the soil and burrow into the skin when such clothes are worn or the person lies on the ground. Usually, the area of maximum and prolonged contact becomes infested, for example, the belt line. Our case probably became infested from the clothes that were dried on the lawn without ironing.

Larvae infestation of the cutaneous tissue results in the development of a pruritic papule of about $2-3 \mathrm{~mm}$ in diameter within 24 hours of initial contact with the larvae. This papule gradually extends, forming a lesion with a diameter ranging from $1-3.5 \mathrm{~cm}$ and height 0.5 to $1.0 \mathrm{~cm}$. The respiratory sinuses and occasionally the - posterior end of the larva itself may be seen through a central punctum. No systemic symptoms are observed.

Infestation caused by the Tumbu fly may become crusted, odiferous, purulent and mayexude serosanguinous discharge. ${ }^{4}$ Because of the resemblance to a bacterial infection, there is a risk of diagnostic failure ${ }^{5}$ which occurred in this case both in a peripheral hospital where the child had received antibiotics and in the tertiary hospital where a swab was to be taken. Histology of the skin tissue reveals inflammatoryresponse with concentration of lymphocytes, giant cells, neutrophils, eosinophils and plasma cells. Secondary bacterial infection is uncommon because of the bacteriostatic activity in the gut of the larva that seems to prevent undesirable overgrowth of pyogenic bacteria. ${ }^{4}$ Movement of the larvae in the skin results in itchy sores, which develop into painful swellings. This six-week-old baby was very irritable, cried excessively and refused feeds; he was probably having severe pains. These lesions rarely develop into significant health risk because when the larvae mature, they make their exit leaving no long-term effects.

Treatment usually consists of the application of jelly to the lesions; this cuts off the oxygen supply to the maggots and forces them closer to the surface where they can readily be extracted. 'Or' (local gel), Vaseline, heavy oil, paraffin, beeswax, nail polish, adhesive tape, butter, chewing gums and mineral oil have all been used. A soak in a bathtub also serves the same purpose. Boggild et al, recently described a new and effective method for extraction of $D$. bominis larvae using a snake venom extractor. ${ }^{6}$ The maggots must be removed completely to reduce the risk of secondary bacterial infection.

Health education is paramount to the prevention of myiasis. In this connection, the mother was advised to desist from drying clothes on the lawn. The knowledge of the disease, its management and prevention is necessary for all health workers in tropical Africa.

\section{References}

1. Veraldi S, Brusasco A, Suss L. Cutaneous myiasis caused by larvae of Cordylobia anthropophaga (Blanchard). Int J Dermatol 1993; 32:1847.

2. Lucchina LC, Wilson ME, Drake LA. Dermatology and the recently returned traveler: infectious diseases with dermatologic manifestations. Int J Dermatd 199;36:167. 81.

3. Adisa CA, Mbanaso A Furuncular myiasis of the breast caused by the larvae of the Tumbu fly (Cordylobia anthropophaga). BMC Surg 2004; 4:5.

4. Mashhood AA Furuncular myiasis by tumbu fly. J Coll Physicians Surg Pak 2003;13:195-7.

5. Johansen LV, Pedersen C, Holm R. Cutaneous myiasis. A case of double infestation with Dermatobia hominis larvae. Ugeskr Laeger 2003; 165:1143-4.

6. Boggild AK, Keystone JS, Kain KC. Furuncular myiasis: a simple and rapid method for extraction of intact Dermatobia hominis larvae. CinInfect Dis 2002; 35:336-8. 